\title{
Feelgood på Lillestrøm
}

\author{
Ravi Gulati var barnelege ved en brannskadeavdeling i India. Alle de tragiske barneskjebnene ble så psykisk \\ belastende at han dro fra sykehuslivet. Til slutt havnet han som allmennlege i Norge. I et hvitt hus på Lille- \\ strøm har han og kona fastlege- og fysioterapipraksis. To av døtrene er også blitt leger. Sønnen hoppet av \\ medisinstudiet, så han er «bare» blitt statssekretær for statsminister Erna Solberg.
}

Å komme inn døren hos familien Gulati er som å komme til India. Og Peru. Og Egypt. En to meter høy elefantskulptur pryder hallen. Persiske tepper, store lysekroner, spisebord i marmor og en rokokkoinspirert sofagruppe trukket i gullfarget silkebrokade pryder stuen.

- Pappa handler souvenirer hver gang vi er ute og reiser. Ikke kjøleskapsmagneter og små modeller av turistattraksjoner, som mange andre, men møbler og tepper og lysekroner, forklarer datteren Geeta.

Her bor pappa Ravi (62), fastlege ved legekontoret vegg i vegg, og kona Sunita (60), fysioterapeut med praksis i kjelleren. Sammen har de barna Annie (35), Geeta (32), lege ved Ahus og doktorgradsstipendiat ved Universitet i Oslo, Dipali (25), straks ferdig turnuslege og Himanshu (26), statssekretær for statsminister Erna Solberg. Huset bærer preg av at familien har reist til minst 100 land sammen. Siden barna var spedbarn er de blitt tatt med på tur, og ofte drar de tilbake til samme sted flere ganger.

- Vi har blant annet vært 13 ganger

i Egypt. Poenget med reisene våre er at de skal være morsomme og opplevelsesrike, særlig med hensyn til historie og kultur. Vi drar ikke på de vanlige badeferiene, heller til mer uvanlige reisemål, som Nord-Korea, Iran, Syria, Libya og Colombia, sier Geeta.

Den ene veggen på kjøkkenet er dekket av store rammer med feriebilder i. Og andre gode minner. Lille Dipali i sari. Lille Himanshu i legekostyme. Mamma Sunita viser oss også flere fotobøker hun har laget. Her har hun dokumentert hver eneste reise og hver eneste bursdag og 17. mai og første skoledag siden barna var små.

\section{Orker ikke mer elendighet}

Når Tidsskriftets utsendte kommer på besøk, er arbeidsdagen akkurat ferdig. Vi er først litt i tvil om hvilken dør vi skal ringe på. Det er tre å velge mellom. Men så kommer det en mørkhåret mann ruslende ut fra den ene. Døren viser seg å føre til legekontoret, og mannen viser seg å være Ravi. Han er på vei hjem, to dører bortenfor, og er lettet over at han ikke ble forsinket med pasientbehandlingen denne dagen - det er ikke hver dag han kan lukke døren bak seg klokken 16. Han har mange pasienter på listen sin, en stor andel av dem er barn.

- Jeg er veldig glad $i$ å ha barn som pasienter, og de er glade i meg. Jeg tar blodprøver på dem selv, for det fungerer best - og vi er fortsatt venner etterpå, sier han stolt. - Men jeg skulle ønske jeg hadde hatt mer tid til pasientbehandling. I dag går det med altfor mye tid til dokumentasjon og byråkrati, mener han.

Sunita har også behandlet dagens siste pasient og er godt i gang med å forberede snacks til oss: frityrstekt spinat og løk,

\section{«Vi barna snakker sognedialekt oss imellom og bokmål med alle andre»}

nytrukket chai latte og de lekreste «indian delights». Ekteparet kom til Norge fra India i 1979. Ravi er opprinnelig barnelege og jobbet ved Safdarjung Hospital i New Delhi. Pasientene hans var alvorlig brannskadede barn, og erfaringene derfra har satt varige, dype spor.

- Jeg husker altfor godt en liten jente som fikk alvorlige brannskader i et badekar, fra dusjen - kokende varmt vann. Hun døde. Flere år etter traff jeg foreldrene hennes på gaten. De var takknemlige for at jeg hjalp dem, men datteren deres var jo død likevel. Det gjorde forferdelig vondt å treffe dem igjen. Alle disse episodene gjorde et sterkt inntrykk på meg. Så sterkt at jeg ikke orker å jobbe på sykehus mer, ikke på noen avdeling. Jeg kan ikke se elendigheter hos pasienter og deres pårørende. Det er feigt kanskje, men sånn er det, sier han.

Derfor ble det allmennpraksis. Der ser han ikke så mye elendighet $\mathrm{i}$ hverdagen, sier han, og sender varme tanker til legene som jobber på sykehus, Radiumhospitalet for eksempel. Det hadde han ikke klart. Han råder andre til å tørre ta vanskelige valg hvis det kjennes rett for dem selv.

- Hvis du ikke liker det du gjør, ikke fortsett med det.

\section{Fra India til Distrikts-Norge}

I Norge var det lett å få jobb, og kona kjente mange fysioterapikolleger. Veien gikk via England, der Ravis bror og svigerinne jobbet som leger, til Bodø. Der jobbet han i tre år til han var nesten ferdig lungespesialist. Broren og svigerinnen kom etter til Norge, og begge jobber nå som overleger ved Haukeland universitetssykehus. Sønnene deres er henholdsvis lege i spesialisering ved samme sykehus og medisinstudent. Men siden sykehusjobbing egentlig var utelukket for Ravi, bestemte den lille familien seg for å flytte fra Nord-Norge til Vestlandet. Nærmere bestemt til den lille bygda Lavik - et idyllisk fergested på nordsiden av Sognefjorden. Her fikk etter hvert Geeta selskap av de to småsøsknene sine. Ravi ble kommunelege og spesialist $i$ allmennmedisin. På dagtid tok han imot pasienter på legekontoret, og hver kveld var han ute på pasientbesøk, i hovedsak med ferge eller egen båt.

- Han reiste rundt med legekoffert og en kjempestor mobiltelefon, sier Sunita, og viser med armene hvor store mobiltelefonene var på den tiden.

Ravi kjente fergemannen så godt at hvis han var litt sent ute kunne han ringe og be fergen vente. Geeta har trådd sine barnesko i Lavik og var mye med pappa på sykebesøk. Hun husker ikke sprøyter og bandasjer, men hun husker at det ble mye kaker.

- Og så var pappa alltid på jobb. Folk kom og banket på døren vår morgen og kveld, minnes hun.

Det var en 24-timers jobb. Med små barn, legekontoret 50 meter unna huset og ingen sykehus eller legevakt i nærheten til å avlaste pågangen, ble det etter hvert vanskelig.

- Det var veldig tøft. Men jeg ble godt kjent med pasientene mine. Jeg husker frem- 


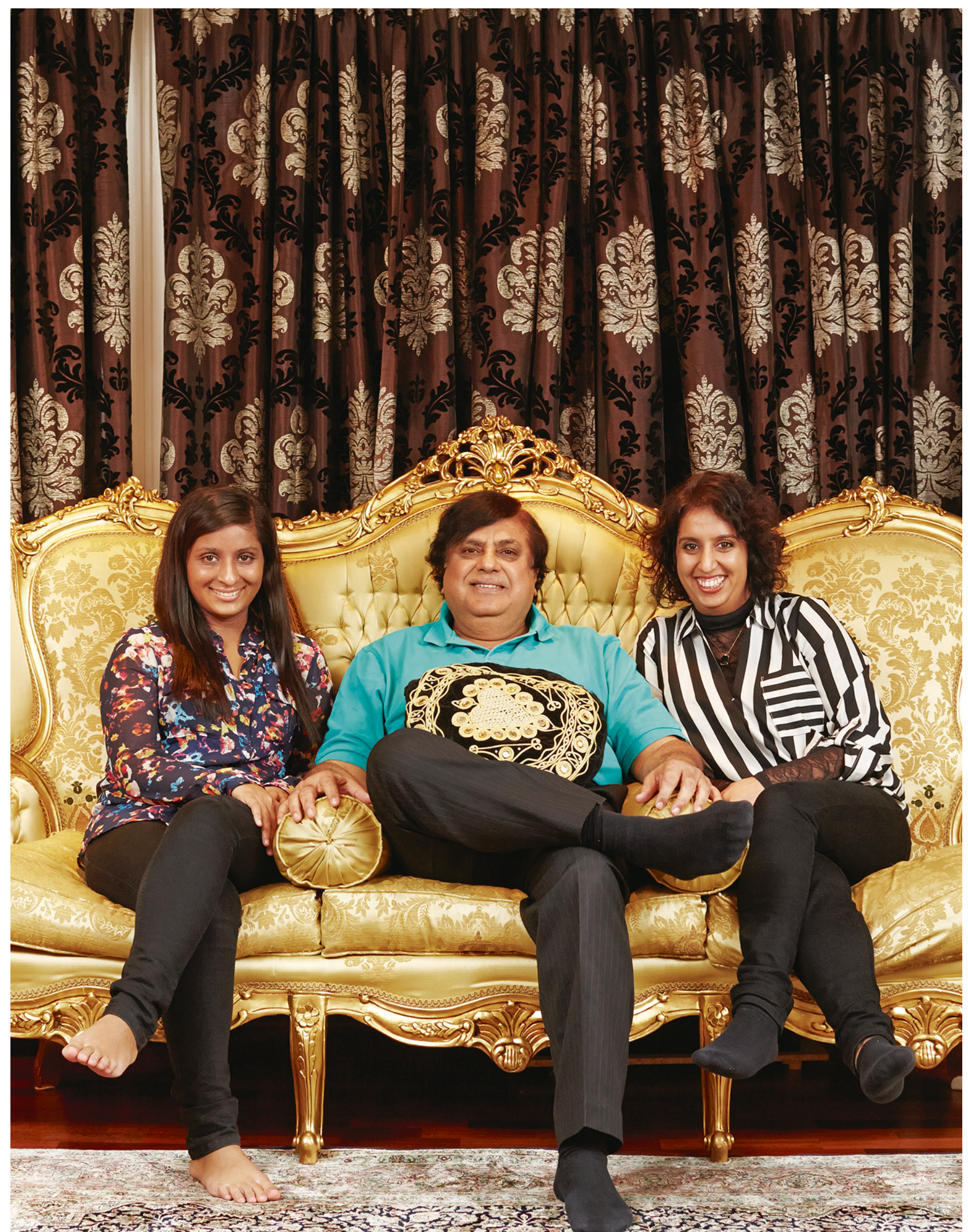




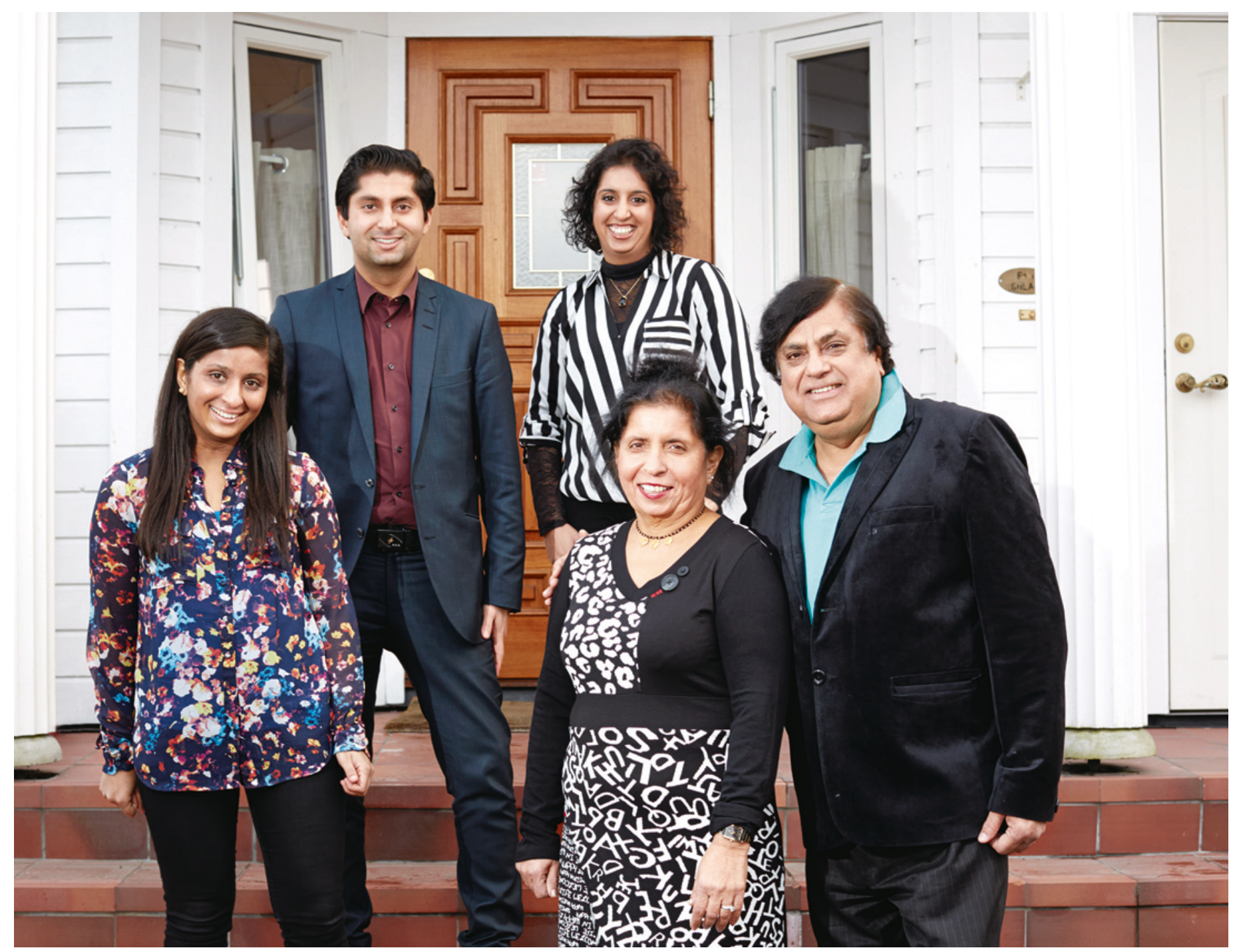

Mamma og pappa Gulati har hjemmet sitt og arbeidsplassen sin i dette huset på Lillestrøm. Barna har delvis vokst opp her, og de er ofte på besøk. Bak f.v Himanshu og Geeta. Foran f.v. Dipali, Sunita og Ravi

deles telefonnummeret og fødselsnummeret til mange av dem. Og av og til ringer de for å få råd. Det er fortsatt ikke lege på sørsiden av fjorden der, vet du.

\section{Barn trenger disiplin og kos}

Det var imidlertid ikke den store pasientpågangen som var årsaken til at de etter 17 år flyttet fra vestlandsidyllen. Derimot var det ønsket om at de to yngste barna skulle gå på en engelsktalende skole. Særlig mamma Sunita sto hardt på det. Hun ville at de skulle gå på en skole med mer disiplin, flere faglige utfordringer og internasjonal eksponering. Så de flyttet til Lillestrøm og kjøpte det hvite huset på Volla. Hver morgen kjørte pappa Dipali og Himanshu inn til Oslo sentrum, og derfra gikk det buss til Oslo International School på Bekkestua. Geeta var for stor, hun startet i 10. klasse på Lillestrøm.

- Himanshu var en alminnelig elev på norsk skole, men etter det første året på Oslo International School ble han «Student of the year» i klassen. Og da ville jo Dipali gjøre det bedre, så hun ble det for hele barneskolen, forteller Ravi stolt.

Da familien ble intervjuet i Dagens Næringsliv for to år siden, under tittelen Tigermammaer fostrer vinnere, kunne vi lese at norskfødte barn av indiske foreldre i mange år har toppet utdanningsstatistikken. De ligger langt over snittet både når det kommer til å fullføre videregående og ta høyere utdanning. Professor Kjell Skogen ga de indiske mødrene æren og mente at norske foreldre kan lære av dem. Både Geeta, Dipali og Himanshu har vitnemål fulle av seksere.

- Hva er oppskriften, Sunita?

- Aldri kjeft, aldri ris, bare kos, ler hun hjertelig. - Bare spør dem!

De tre nikker bekreftende. De mener selv at de er bortskjemte og kan tvinne foreldrene rundt lillefingeren. Men foreldrenes forventninger har likevel gjort at de har jobbet hardt for å komme dit de er i dag. Og de snakker flytende engelsk, hindi, norsk bokmål og sognedialekt.

- Vi barna snakker sognedialekt oss imellom og bokmål med alle andre. Det er mest naturlig for oss. Og mamma og pappa snakker konsekvent hindi med hverandre. Da vi var små, nektet pappa å snakke norsk med oss, for han ville at vi skulle lære oss hans morsmål. Hvis vi spurte ham om noe på norsk, svarte han ikke før vi sa det på hindi. Mamma snakket bare engelsk med oss, forteller Dipali.

\section{«Alt går over»}

Etter et par års pendling til Oslo åpnet Ravi og Sunita sin egen praksis på Lillestrøm. Da de kjøpte det hvite huset på Volla, var det gynekolog June Theisen som holdt til der. 
Hun hadde et lite kontor i 2. etasje. Det gjorde det enkelt for ekteparet Gulati, for da kunne de fortsette legepraksis på adressen. I 15 år har de jobbet sammen.

- Det har gått veldig fint hittil, i alle fall, ler Sunita.

Med unntak av alle pasientene som ringte på til alle døgnets tider da de bodde i Lavik, har ikke de tre barna merket så mye til foreldrenes praksis - til tross for at det er i samme hus. Å vokse opp med en lege til far betydde imidlertid at de aldri var syke. Tilsynelatende.

- Når du er liten og syk, vil du jo gjerne ha litt oppmerksomhet og trøst. Men nei da. «Alt går over», var pappas innstilling. Han målte ikke temperaturen eller ga oss antibiotika eller noen ting. Det var så skuffende! Sånn sett var det mamma som var legen i huset, sier Geeta.

Vi har kommet opp trappen til andre etasje, og også her åpenbarer det seg en liten kinosal. I helgene samles ofte familien, og det er ikke alltid de er enige om hvilken film de skal se. Filminteressen deler de, men for noen av dem går det helst i Bollywood, mens andre foretrekker Hollywood. Hele garasjen er full av kassetter med filmer fra hele verden. Tusenvis.

- Pappa er en av Indias største samlere av gamle filmer og indisk musikk, forteller Geeta.

Ravi tør ikke bekrefte det. Men han bekrefter at han har vært på indisk riksdekkende TV og fortalt om samlingen sin, og at de der påsto at det var Indias største. Musikkinteressen startet da han var ganske liten, og det vanket mye kjeft hjemme og på skolen fordi han hørte så mye på musikk. Til hans store glede har alle barna arvet filminteressen, aller mest Himanshu. Det fristet ham til og med vekk fra medisinstudiet i sin tid.

- Legeyrket var egentlig det eneste yrket jeg visste om da jeg var liten, så det var hele tiden det jeg trodde jeg skulle bli, forteller Himanshu. - Jeg jobbet mot det målet på videregående også, men ble mer og mer i tvil. Etter videregående dro jeg derfor på filmskole i Mumbai i et halvt år. Da jeg kom tilbake, prøvde jeg meg på medisinstudiet, men skjønte fort at det ikke var noe for meg, så jeg hoppet av etter første semester og begynte på økonomistudier i stedet, forteller han.

\section{Som en katastrofe å regne}

For pappa var det helt greit at han ikke ville bli lege. Mye jobb og lange vakter, mente han. Men han ble likevel litt skuffet da han sluttet. For mamma Sunita var det verre. Som en katastrofe å regne.
- Ja, jeg syntes det var vanskelig å godta. Han som kledde seg ut som lege hver gang det var karneval i barnehagen og på skolen. Det er et av de mest anerkjente yrkene vi har, og han hadde i tillegg kommet inn på medisinstudiet i Oslo!

- Det var på en måte idiotisk, skyter Ravi inn. - Eller et paradoks, kanskje. Men til slutt innså vi at han hadde handlet rett, sier han.

Himanshu endte opp i politikken og har raskt steget i gradene i Fremskrittspartiet. Nå sitter han som statssekretær for statsminister Erna Solberg.

- Det er bra nok det, eller?

- Sånn passe, humrer Sunita lurt.

At alle barna har arvet pappas film- og musikkinteresse er én ting, men at yngste-

\section{«Da barna skulle vaske hendene før maten i barnehagen, vasket Geeta seg alltid på kirurgmåten»}

datteren har arvet pappas hang til å se på sport er verre. Mamma var fortvilet over datteren da hun skulle ha 12. semestereksamen på medisinstudiet. Samtidig var det nemlig World Cup i cricket på TV.

- Det siste året på medisinstudiet. Hele pensum! Og så sitter hun ved PC-en og ser på TV i fire dager! Da var jeg alvorlig bekymret. Og ikke bare det - hun sa «Det skal bli godt å bli ferdig med eksamen så jeg kan se mer cricket».

- Lesesal har aldri vært min greie, forklarer Dipali. - Sånn er det bare.

- Både du og pappa har vel sett mer TV enn dere har lest bøker under studiet, ler Geeta.

Geeta har hele tiden visst at hun skulle bli lege og har jobbet mot målet siden barneskolen. Da barna skulle vaske hendene før maten i barnehagen, vasket Geeta seg alltid på kirurgmåten. Hender og underarmer ble såpet grundig inn - og skylt. Hele genseren ble våt - hver dag. «Pappa er jo lege», bedyret hun, så slik måtte det gjøres. Dipali har ikke vært like sikker og vurderte en stund å bli fotograf. Hun har fătt med seg et par somre på fotografskole i New York og på filmskole med sin far i Oxford. Men når vi er på besøk, er hun tre dager unna å fullføre turnustjenesten ved Ahus. Det ble legeyrket til slutt likevel.

\section{Ber ikke hverandre om råd}

Alle tre har en litt ulik tilnærming til yrket. Dipali tiltrekkes av internasjonalt arbeid og Leger uten grenser. Hun har allerede vært i Ghana på klinisk utveksling og er blitt svært fascinert av fødselshjelp. Hun har også vært på utveksling i Sverige og Australia. I tillegg har hun her hjemme vært aktiv i Medisinernes seksualopplysning og Norsk medisinstudentforening. Geeta på sin side er godt inne på forskningssporet og har fått smaken på kardioonkologi. Hun er svært engasjert i prosjektet sitt, som handler om å forebygge hjertesvikt hos pasienter med brystkreft som får cellegift.

- Jeg har alltid vært glad i forskning, og det var så gøy da jeg fikk et stipendiattilbud fra professor Torbjørn Omland, som også er internasjonalt veldig kjent. Vi jobber med en studie som har et veldig morsomt akronym: PRADA-studien. Jeg holder på med doktorgraden innen kardioonkologi og har en Bgrenstilling ved Hjerteavdelingen, Ahus. Planen er å bli på Ahus.

Engasjementet til Geeta smitter. I 2012 sendte både dommere og publikum henne til topps i Forsker Grand Prix Oslo med foredraget hun holdt: «Hjertesorg» av cellegift.

- Det var så gøy! Jeg fikk gode retningslinjer og er jo veldig engasjert i dette. Det rammer så mange. Alle kjenner noen med brystkreft, og alle vet hva hjertesvikt er. Vi er nesten ferdige med datainnsamlingen nå, det er kjempespennende og også et «hot» tema internasjonalt, sier hun engasjert.

- Dere er tre leger i samme familie og jobber i tre ulike felt. Går dere til hverandre for faglige råd?

- Ikke så mye. Da jeg var i turnus og kom i distrikt, hendte det at jeg ringte pappa hvis jeg hadde spørsmål. Heller det enn å plage veilederen eller ringe sykehuset. Men ikke nå lenger, sier Geeta.

- Dipali, du er jo i turnus nå. Hender det ikke at du ringer pappa?

- Nei. Aldri.

- Jeg ringer Dipali av og til, skyter pappa inn. - Hun har jo fått nye impulser. Praksis er den samme som før, teknikken er litt annerledes, mens teorien har forandret seg ganske mye. Så jeg spør henne for eksempel om infeksjonsmedisin, sier han.

- Både Dipali og jeg har vært på tropemedisinkurs i utlandet, men av en eller annen grunn ringer pappa alltid Dipali. Men hun er jo diagnostikeren i familien vår, da. Hun kommer på alle slags diagnoser. Så kommer de til meg for behandlingen og til pappa for å verifisere at alt er riktig. Det er en tretrinnsprosess, ler Geeta. 


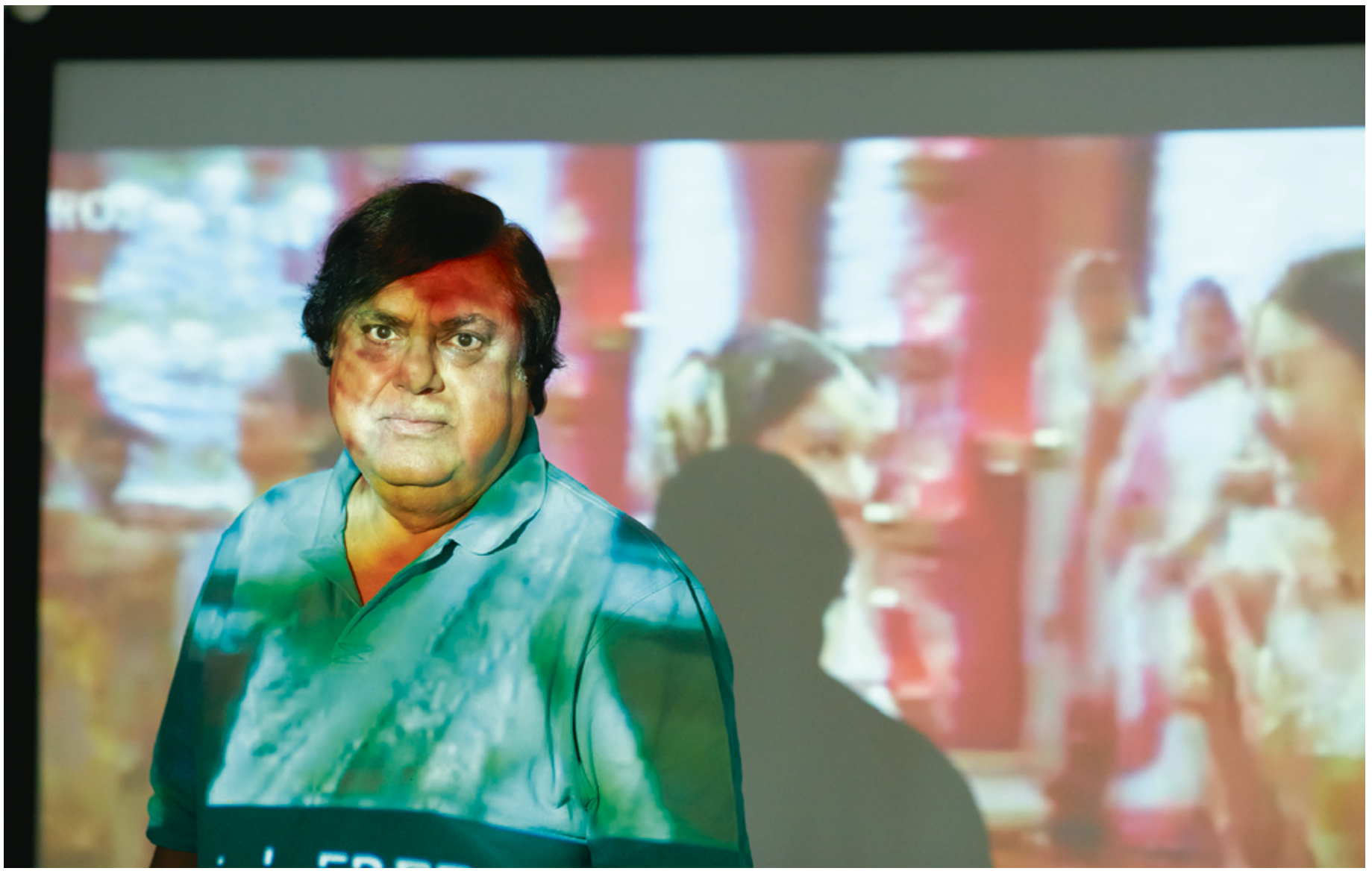

Ubekreftede rykter - og indisk riksdekkende TV - sier at Ravi Gulati er en av Indias største samlere av gamle filmer og indisk musikk. Hjemme i stuen har han en storskjerm, og med surroundanlegg i tillegg blir det mange gode filmopplevelser

\section{Gynekolog? Virkelig?}

Faglige uenigheter har de ikke mange av. Bortsett fra hvilken gren lillesøster skal velge, da. Storesøster vil ha henne inn i sitt felt, mens pappa er mest opptatt av å få henne vekk fra gynekologi.

- Det har vært litt krig her i det siste ja, om hva hun skal gjøre videre. Hun var i Bergen, ved Gynekologisk avdeling. Hun vil helst bli gynekolog. Hun fikk jobb også!

- Oi, gratulerer!

- Jo takk. Men jeg sa nei, ler Dipali. - Samme dag fikk jeg tilbud om å jobbe ved Infeksjonsmedisinsk avdeling, Ahus. Det var et vanskelig valg, for jeg liker begge feltene og begge stedene. Men infeksjonsmedisin er utrolig spennende, og avdelingen på Ahus er helt fantastisk med veldig flinke folk. Men gynekologi og dermatologi er også veldig interessant, og aller mest spennende er internasjonalt arbeid. Så det er mange muligheter for fremtiden. Alle dører er åpne, sier Dipali.

\section{Kjøttkaker og norsk smør}

Ingenting å si på forventningene der i gården. Latteren sitter løst. Det gjør praten også.
De fullfører gjerne setningene for hverandre og er flinke til å løfte hverandre frem. Særlig vil Ravi ha et ord med i det som blir sagt. En patriark av det milde og omsorgsfulle slaget. Geeta prøver å komme til orde innimellom, mens Dipali er mer beskjeden og stille.

\section{«Vi snakker veldig}

\section{lite medisin sammen.}

\section{Hele livet handler ikke}

\section{om det»}

Himanshu er den mest ordknappe FrP-politikeren vi har vært borti. Men det har kanskje med situasjonen å gjøre. Han viser oss imidlertid hvordan en ekte Bollywood-film oppleves på stort lerret. Hele den ene veggen i stuen dekkes av dansende vakre kvinner i fargerike sarier og kjekke menn med dådyrøyne. Ut av surroundanlegget strømmer fengende, indisk filmmusikk og inderlig romantisk sang. Vi skulle gjerne blitt hele kvelden, vi. Sett film, snakket tull og spist mer indisk pakoda. Skjønt, hadde Geeta fått velge hadde det kanskje blitt kjøttkaker.

- Geeta elsker å spise, og hun elsker norsk mat, kan pappa fortelle. - Da hun var mindre, og vi hadde vært ute og reist, måtte vi ofte stoppe på en veikro på vei hjem fra Flesland, for hun hadde så fryktelig lyst på kjøttkaker med brun saus og ertestuing, ler han.

- Og Himanshu elsker norsk smør. Når vi har vært på tur, har vi alltid pakket med oss knekkebrød, leverpostei, brunost og smør. Andre nordmenn ler av oss når de ser oss pakke frem maten på flyet, skratter mamma.

Humoren i familien er upåklagelig, og latteren sitter løst. Vi ler av at Dipali, som til stor underholdning for sine turnuslegekolleger, kjører rundt i en lekker Jaguar. Forklaringen er at pappa ikke orker å kjøre bil mer, og siden han uansett betaler årsavgift og forsikring bør jo bilen kjøres av noen. Vi ler av at Ravi og Sunita har gått til innkjøp av en jacuzzi på terrassen, og at barna tror de hadde baktanker med kjøpet: å samle barna hjemme enda litt oftere. Det virket. Og vi ler av at Geeta som naiv elev på videregående 
tok med seg en penn hjemmefra - hun valgte alltid den fineste hun fant fra pappas legemiddelkonferansesamling - og ikke forsto lærerens reaksjon da hun fikk låne pennen. Viagra var nemlig ikke i den unge elevens vokabular på den tiden. Også spørsmålet vårt om hva det beste de har opplevd som leger er, vekker latter.

- Det beste tror jeg er fødsler, sier Dipali.

- Ha, ha, det eneste hun er opptatt av, er fødsler, brummer pappa Ravi.

- Ja, men det er jo den største dagen i manges liv! Å få være en del av det er helt spesielt, sier datteren bestemt.

\section{Fødsler og kriminalhistorier}

En fødsel er også noe av det tøffeste hun har opplevd som lege.

- I Ghana var jeg med på et keisersnitt, vi skulle forløse tvillinger. Plutselig, midt under inngrepet, stoppet hjertet til moren. Anestesilegen ante ikke hva han skulle gjøre, så det ble helt kaos. Gynekologen begynte å gjøre hjerte-lunge-redning. Han fikk liv i henne, men hun døde etterpå. Det gjorde inntrykk, sier Dipali alvorlig.

Geeta husker en episode fra turnustjenesten i psykiatrien som satte en liten støkk i henne.
- Jeg ville ikke gå med vaktcallingen før jeg hadde vært med på minst én telefonsamtale eller innkomst. Men så kom aldri denne innkomsten, og plutselig hadde det gått en uke. Til slutt sa kollegene mine at nå måtte jeg ta vaktcallingen. «Hva er det verste som kan skje?», spurte de. Etter to minutter ringte den. Det var fra kirurgen: «Det står en mann i fjerde etasje og skal hoppe!» Geeta ble paff og handlingslammet, og akkurat den telefonen var i grunnen det verste som kunne skje, mente hun. Men etter hvert fikk hun summet seg og fikk etter litt leting med seg overlegen opp til fjerde etasje.

- Da vi endelig kom frem, skulle vi ikke gjøre noe likevel, for det er visst politiet som skal snakke disse pasientene ned fra vinduet. Psykiateren har ikke lov til å gjøre noe før pasienten står på gulvet. Politiet gjorde en kjempejobb og fikk ham ned, og så ble han med oss ned på psykiatrisk avdeling.

For Ravi er episodene fra brannskadeavdelingen i India de tøffeste. Nå vil han heller fortelle gode historier fra da han var lege i Oslo kretsfengsel, det første året de bodde på Lillestrøm.

- Politiet kom inn til meg med en pasient som jeg tror var nynazist. Da han så meg, ropte han: «Den svartingen der, han skal ikke jeg til! Jeg vil ha en annen lege!». Politimannen fortalte at det ikke fantes noen andre leger på huset. Og betjenten kjente meg godt, så han sa: «Bare gå til ham. To minutter. Så skal du få se». Han ble der i en og en halv time. Etter den dagen kom han til meg hver dag, med stadig nye unnskyldninger for at han måtte til legen, ler han.

Historiene kommer på løpende bånd, og de tre i gullsofaen kjenner etter hvert at det er fint å friske opp minnet om alt som har skjedd de siste årene. På godt og vondt. Det er ikke så ofte de snakker fag eller jobb her hjemme.

- Vi snakker veldig lite medisin sammen. Hele livet handler ikke om det, smiler Dipali.

Storesøsteren er enig.

- Der er vi kanskje forskjellige fra en del andre legefamilier. Vi snakker lite medisin hjemme. Jobben er jobben. Rundt middagsbordet snakker vi heller om reisene våre.

- Vet du forresten hvor verdens vakreste solnedgang er? spør Ravi plutselig. - På Lillestrøm!

\section{Eline Feiring}

Tidsskriftet 